Boise State University

ScholarWorks

Public Policy and Administration Faculty

Publications and Presentations

Department of Public Policy and Administration

4-2011

\title{
Analysis of Carbon Capture and Sequestration Pore Space Legislation: A Review of Existing and Possible Regimes
}

\author{
Elizabeth L. Aldrich \\ Boise State University \\ Cassandra Koerner \\ Boise State University
}

This is an author-produced, peer-reviewed version of this article. (c) 2009, Elsevier. Licensed under the Creative Commons Attribution-NonCommercial-NoDerivatives 4.0 International License (https://creativecommons.org/ licenses/by-nc-nd/4.0/). The final, definitive version of this document can be found online at The Electricity Journal, doi: 10.1016/j.tej.2011.03.001 
NOTICE: This is the author's version of a work accepted for publication by Elsevier. Changes resulting from the publishing process, including peer review, editing, corrections, structural formatting and other quality control mechanisms, may not be reflected in this document. Changes may have been made to this work since it was submitted for publication. The definitive version has been published in The Electricity Journal , Volume 24, Issue 3, 2011. DOI: 10.1016/j.tej.2011.03.001

\title{
Assessment of Carbon Capture and Sequestration Liability Regimes
}

\author{
Elizabeth Lokey Aldrich, Boise State University ${ }^{1}$ \\ Cassandra Koerner, Boise State University
}

\footnotetext{
${ }^{1}$ The authors would like to thank Melisa Pollak, Research Fellow in the Science, Technology and Public Policy Program at the University of Minnesota Humphrey School of Public Affairs, for her insight into the state-level carbon capture and sequestration liability legislation that is analyzed in this paper.
} 


\section{Table of Contents}

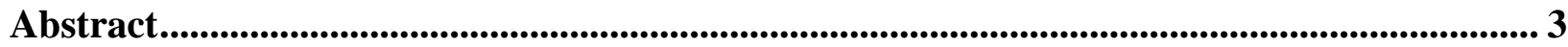

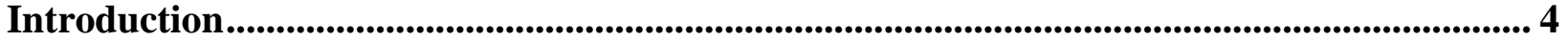

Short -Term Liability ......................................................................................................................... 4

Long-Term Liability .............................................................................................................. 6

Long-Term Liability Instruments ...................................................................................... 6

Comprehensive Industry-Pooled Liability Funds with State Indemnification .............................. 6

North Dakota............................................................................................................................ 7

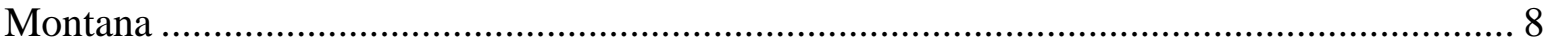

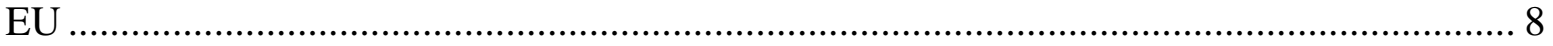

Industry-Pooled Funds for Long-Term Monitoring and Remediation ....................................... 9

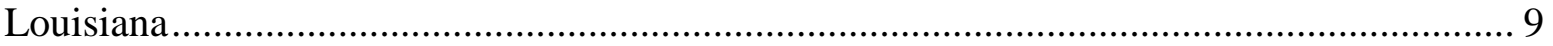

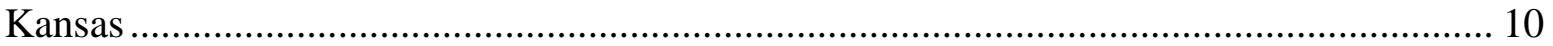

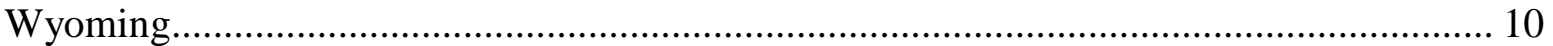

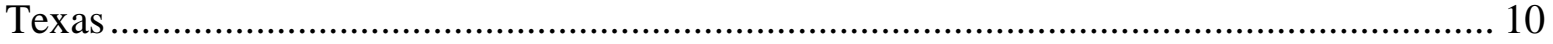

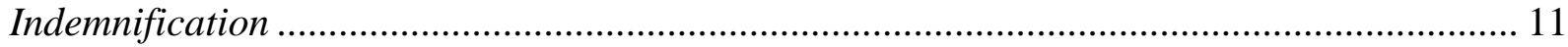

Three-Tiered Liability ....................................................................................................... 12

Analysis and Recommendation of Best Scheme............................................................................ 14

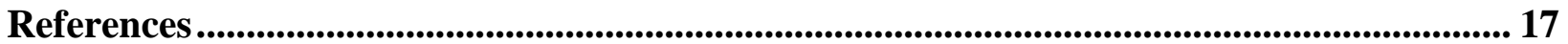




\begin{abstract}
Liability coverage for carbon capture and sequestration (CCS) is of paramount importance if the industry is going to mature and develop in a way that will allow it to make a significant contribution to mitigating climate change. Liability for CCS can be broken into two phases short-term, which covers the pre-injection, injection, and closure stages of the project, and longterm, which covers the post-closure stage. Since pre-injection, injection, and closure occur over a relatively short period of time that may cover 20-30 years, typical liability instruments like private insurance, letters of credit, performance bonds, trust funds, and escrow accounts may be utilized. For the post-closure phase, which lasts indefinitely after the site has been closed, more enduring liability instruments must be used in order to ensure that adequate and long-lasting coverage is provided. Several states have created liability schemes to cover long-term liability, but most of these schemes are incomplete and may lead to confusion over who is responsible for damages and remediation if they are utilized. This paper discusses possible liability schemes, critically analyzes those schemes currently in place, and proposes the best possible choice for long-term coverage of geological sequestration.
\end{abstract}




\section{Introduction}

The United States uses coal for nearly 50 percent of its electricity production (EIA, 2010a), and, compared to other fossil fuels like oil and natural gas, coal releases more carbon dioxide (CO2) when combusted (EIA, 2010b). Due to the warming potential of the CO2 released, separation of $\mathrm{CO} 2$ from stack emissions and sequestration of the CO2 in geologic reservoirs is being pursued avidly with public and private research. Carbon capture and sequestration (CCS) could prevent the release of up to 90 percent of $\mathrm{CO} 2$ emissions at a stationary power plant or industrial facility if $\mathrm{CO} 2$ were captured directly at the source, separated from other by-products, transported to a geologic formation, and stored for an indefinite period of time (Pacala \& Socolow, 2004).

There are some risks to human and environmental health associated with carbon injection. CO2 presents risks to plant life by raising the CO2 levels in the soil. Large releases of CO2 in the soil can be lethal to plants and animals (Klass \& Wilson, 2009). Human health can also be at risk from the effects of $\mathrm{CO} 2$ in the subsurface where the injection displaces brine and mixes with and degrades the quality of subsurface water reservoirs. Subsurface aquifers are highly regulated and will be monitored carefully through safeguards put in place by the new Environmental Protection Agency (EPA) Underground Injection Control Class VI well rule. (This new regulation will be discussed in detail later in the paper.) Maintaining the stability of the subsurface looms as another potentially large risk that must be managed. Researchers reported several earthquakes, some between 3 and 4 on the Richter scale, in the Denver area following the injection of waste fluids into subsurface spaces (Healy et. al., 1968), and more recently concerns have erupted in Arkansas over hydraulic-fracturing (fracking) which seems to be having a similar seismic impact in shale laden areas (Eddington, 2011).

Given the risks described above, liability schemes are emerging to protect against these risks in both the short- and long-term. Recent allegations against Cenovus, the primary carbon injector at the Weyburn site in Saskatchewan, claim that the site has sprung a leak and is threatening health and human safety on lands surrounding the oil field/injection site (Petro-Find Geochem, 2010). The Weyburn situation is the first allegation of leaked CO2 made in regards to large-scale carbon injection worldwide and may highlight the need for greater attention to the risks and liabilities associated with CCS.

\section{Short -Term Liability}

There are three main stages of CCS, which include capture, transport, and sequestration of the $\mathrm{CO} 2$. Within the sequestration phase, there are three separate stages, which include operation, closure, and post-closure; each of these phases has its own associated risks. The time of preinjection and operation occur over a period of approximately 20-30 years, which established insurance products can cover (Klass \& Wilson, 2008). The length of time defined as “closure,” before a final authority assumes responsibility for the site, depends on the jurisdiction; in Montana, the waiting period before the state assumes responsibility is 30 years, in Australia the time period is 15 years, and in the EU it is 20 years (Jacobs \& Stump, 2010). Given these relatively short time frames, short-term liability instruments are most appropriate to cover the operation and closure phases. Post-closure necessitates long-term liability since it spans an indefinite period of time. 
Many of the short-term risks associated with carbon sequestration have been based on decades of experience injecting carbon for enhanced oil recovery (EOR) purposes (US DOE, 2011). Some expected operational liabilities include the following: injury to workers, difficulties earning access to storage/access rights, poor well construction, poor siting of wells in areas of low injectivity, surface and subsurface property damage, induced seismicity, groundwater contamination, environmental damage, damage to confinement zone, and atmospheric release of CO2 (NETL, 2009). Site closure often requires additional financial assurances to guarantee well plugging and monitoring (Texas General Land Office et. al., ${ }^{2} 2010$ ). The expectation is that as time passes, the risk levels of geologic sequestration will decrease after operations cease. See Figure 1 for a representation of how risk is expected to taper before, during, and after the closure period.

Figure 1: The Timing and Severity of CCS Risks (Adapted from Wilson et. al., 2007)

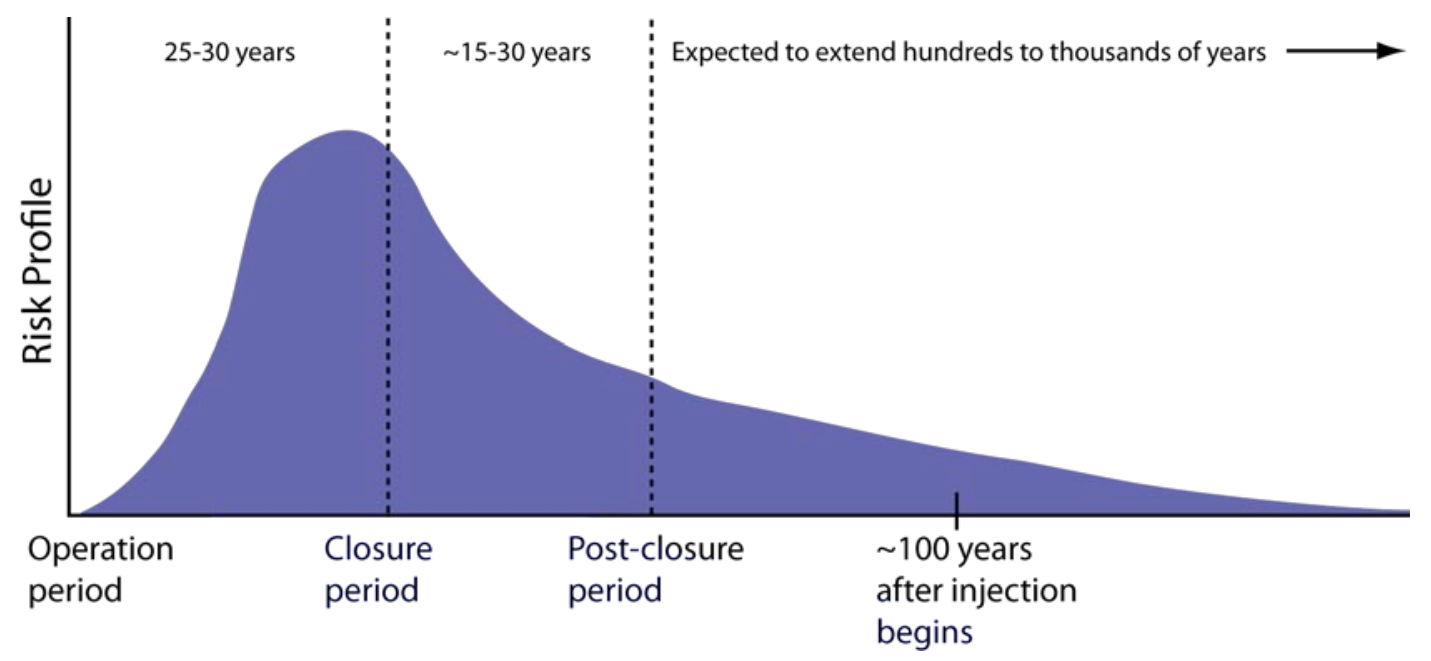

Given the dramatic difference in the amount of risk associated with the distinct phases geologic sequestration, it is only appropriate that different liability schemes be used during these times. For the operation and closure stage of CCS, a variety of products including private insurance, bonding, trust funds, escrow accounts, and other mechanisms are appropriate. The EPA's Underground Injection Control's Class VI Well Rules that were finalized in 2010 call for use of these instruments to cover short-term liability. ${ }^{3}$ All of these options are possible due to the limited time frame of injection and closure, which could be defined as anywhere between five and 50 years. Because the closure time frame is short, there is reasonable assurance that the institutions providing the coverage will be in existence throughout the duration of the project, and various entities like private insurance companies are willing to take on that risk. For this limited time frame, policies can be put in place that provide recourse action if the institutions fail. The more interesting question arises when one considers long-term liability schemes.

\footnotetext{
${ }^{2}$ Hereafter referred to as “Texas.”

${ }^{3}$ While short-term liability can be covered comprehensively using a variety of the short-term liability tools available, long-term liability is less well defined in the Class VI rule. Despite a 50-year closure period suggestion, the EPA can extend liability and hold the owner and operator of the site responsible for damages indefinitely (Federal Requirements under the Underground Injection Control Program for CO2 Geologic Sequestration Wells, 2010).
} 


\section{Long-Term Liability}

One of the primary concerns in the post-closure phases is maintaining the $\mathrm{CO} 2$ plume in the allotted space for centuries. The IPCC notes in its 2005 Special Report on Carbon Capture and Storage that there is little concern over seepage at well-selected sites and even minimal releases will be acceptable so long as they do not affect human and environmental health. The IPCC (2005, p. 34) reported that CO2 storage in an "appropriately selected and managed reservoir is very likely ${ }^{4}$ to exceed 99 percent over 100 years, and is likely to exceed 99 percent over 1000 years."

However, the large amount of CO2 that would need to be sequestered in order for CCS to make a significant contribution to the mitigation of climate change creates this concern for leakage despite the IPCC's prediction. An $800 \mathrm{MW}$ coal-burning power plant will necessitate between 300 to $11,000 \mathrm{~km}^{2}$ of pore space to store the CO2 from this plant for 30 years ${ }^{5}$ (Gresham, 2010). The increased volume and pressurization anticipated by CCS requires a certain type of stable geologic formation if operators intend on sequestering a great volume at a high pressure over thousands of years. Poor siting could lead to the aforementioned physical damages, and could cause carbon credits to be owed to a regulatory body in a carbon-constrained policy environment.

\section{Long-Term Liability Instruments}

The types of long-term liability schemes that exist or are contemplated include comprehensive liability funds, funds that cover only monitoring and remediation, total indemnification of a site by the state or federal government, and a three-tiered scheme that blends personal insurance with industry pooling and federal indemnification. ${ }^{6}$ As each of these liability instruments is discussed, existing liability schemes of each type will be analyzed, and gaps in liability schemes will be highlighted to show how the existing schemes may fail to provide the comprehensive coverage necessary to allow for full commercialization of CCS.

\section{Comprehensive Industry-Pooled Liability Funds with State Indemnification}

Some experts have suggested the government (or a private entity with government oversight) create a fund that multiple operators would pay into to cover liability rather than use private insurance. This method would pool risk for multiple operations through a required contribution or fee program which would likely be based on the project size (metric tons of CO2 injected). Having operators pay into this fund during operations could promote responsible action if the amount being paid were tied to risk assessments (Interagency Task Force on Carbon Capture and Storage, 2010).

Federal compensation systems built off of basic pooling mechanisms have also been discussed by several authors (Klass \& Wilson, 2008; Interagency Task Force on Carbon Capture and Storage, 2010). This program would be modeled after a portion of the Price-Anderson Nuclear Industries Indemnity Act of 1957, which will be described in more detail in the three-tiered

\footnotetext{
${ }^{4}$ 90-99\% probability

${ }^{5}$ The huge discrepancy in these numbers is due to the depth of the formation and its ability to sequester CO2.

${ }^{6}$ Other options for insurance schemes used to cover catastrophic events like floods, hazardous waste, and oil pipelines will not be covered because they are already covered in an EPA report and are not perfect corollaries for CCS (EPA, 2008).
} 
liability section, and CERCLA of 1980 (US EPA, 2008). Under CERCLA, strict, joint, and several liabilities, which could make any of the parties participating in the project potentially responsible for damages to the environment, applies. If none of these entities is found responsible or can be identified and pay, then cleanup is paid for by the fund from the Superfund tax collected from chemical and industrial industries. Alternatively, the industry-pooled fund could be based off the Oil Spill Liability Trust Fund (OSLTF), which is funded by a per-barrel tax on petroleum produced or imported in the US (Jacobs \& Stump, 2010).

Application of this type of pooling mechanism for CCS has been proposed and would entail the collection of a charge per metric ton of $\mathrm{CO} 2$ injected. Alternatively, the fund could be collected based on a fee on all major CO2 emitters, which would involve taxing many entities that do not engage in CCS. This fee would more closely resemble the fee that on-shore petroleum producers pay into the OSLTF since only oil producers that use vessels or deepwater ports would take advantage of the fund (Jacobs \& Stump, 2010). Due to the resistance that this type of fund may face, most funds contemplate the collection of fees on a per metric ton injected basis. Most of the proposed pooling plans with comprehensive coverage and state indemnification omit strict, joint, and several liability in order to encourage the CCS industry (Rankin, 2009).

Within the US, six states have also created industry-pooled funds to cover monitoring of sites, and the EU has created a fund to cover liability into the future. However, these schemes differ in coverage and approach, with some states creating a long-term stewardship fund that requires the state to assume only limited long-term liabilities. Other states created a stewardship fund but require the state to assume all long-term liability. It is also interesting to note that in contrast to the states that have created liability schemes, some states like Oklahoma, Utah, Washington, and West Virginia have passed legislation creating state-level permitting for CCS, but these states have refrained from creating any schemes to cover liability. It is possible that these states expect that liability will be covered at the federal level in future years. Even in Wyoming which has a limited liability scheme, Governor Dave Freudenthal has noted that the federal government will have to "address the long-term liability . . . as no state will be able to assume the risk" (Freudenthal, 2008).

\section{North Dakota}

North Dakota has created two funds for geologic sequestration, one for administrative expenses during site operation, and the other for long-term site management (North Dakota SB 2095 §3822-14 \& 38-22-15, 2009). The short-term site management fund is reserved for "defraying the commissions' expenses in processing permit applications; regulating storage facilities during their construction, operational, and preclosure phases; and making a storage amount determination” (North Dakota SB 2095 §38-22-15(2), 2009). The long-term site management fund is broadly authorized to cover "expenses the commission incurs in long-term monitoring and management of a closed storage facility” (North Dakota SB 2095 §38-22-14(2), 2009). The short-term fund requires operators to pay $\$ .01 /$ metric ton injected while the long-term fund requires \$.07/metric ton injected (North Dakota Industrial Commission, 2010). The state explicitly takes on all long-term liabilities by acquiring title to the injected CO2 and the storage facility and states that "Title acquired by the state includes all rights and interests in, and all responsibilities associated with, the stored carbon dioxide.” The legislation also releases the operator from all regulatory responsibilities (North Dakota SB 2095 §38-22-17(6), 2009). North 
Dakota legislation adds the caveat that the state will be responsible for long-term CCS site monitoring and management just until the federal government takes responsibility.

\section{Montana}

Montana set up a fund for long-term site management with SB 498 in 2009. However, this fund is different from other states in that operators have the option to voluntarily retain long-term liability, in which case they are not required to pay into the fund (Montana SB 498 §2, 2009). This fund is broadly authorized to cover monitoring and managing geologic storage reservoirs after the operator has fulfilled all required closure procedures 15 years after injection has stopped, at which point the state takes title. The amount required by operators to be put into the fund has not yet been decided. The state explicitly takes on all long-term liabilities by acquiring title to the injected $\mathrm{CO} 2$ and the storage facility by saying "Title acquired by the state includes all rights and interests in and all responsibilities associated with the geologic storage reservoir and the stored carbon dioxide” (Montana SB 498 §4, 2009). Montana grants the operator a broad release from liability in verbiage that says "the geologic storage operator and all persons who generated any injected carbon dioxide are released from all regulatory requirements and liability associated with the geologic storage reservoir and the stored carbon dioxide” (Montana SB 498 $\S 4,2009)$.

\section{$\underline{\mathrm{EU}}$}

Not only do examples of long-term liability instruments that are in use exist in the US, the EU has taken steps to address long-term liability as well. The EU has created a set of rules to guide the injection and storage of $\mathrm{CO} 2$ and created a skeleton of a fund and system to cover long-term liability of the site. However, many details of these rules have not been outlined in a detailed way since they will be modified and implemented by national authorities. These rules are laid out in Directive 2009/31/EC (2009) of the European Parliament and of the Council and were created on April 23, 2009. The Directive demands sites be safeguarded during and after operations, but relies heavily on national-level authorities to carry out the enforcement of these safeguards (Official Journal of the European Union, 2009).

The Directive requires that the operator make a post-closure plan that is approved by a national authority. Monitoring must be done during the project by the operator and should be enforced by the appropriate national authority. For post-closure monitoring, the operator should make a financial contribution into a fund that national authorities will use to monitor leakage in the future. The expectation is that the operator pay at least enough into this fund to cover 30 years of monitoring. The EU Directive leaves much of the details about the amount that emitters will pay into the fund and how it will be used up to the national governments (Official Journal of the European Union, 2009). The EU's assumption that monitoring will be carried out by national authorities with proceeds from the fund reflects the fact that the subsurface minerals are owned by the national government of each country.

Liability for environmental damage of protected species, natural habitats, water, and land is not covered specifically by this Directive, but instead is covered under a previous Directive (Directive 2004/35/EC, 2004). Liability for climate change associated with leaked CO2 is covered by the inclusion of storage sites in Directive 2003/87/EC (2003), which requires the surrender of European Union Allowances (EUAs) to repay the leaked amount. If the owner of 
the site was not able to repay these leaked metric tons because the leak occurred far into the future, then it is possible that the federal government would be able to pay for these leaked metric tons and any other damages that occur since the EU Directive does allow liability to be transferred to the national government (Official Journal of the European Union, 2009).

\section{Industry-Pooled Funds for Long-Term Monitoring and Remediation}

Louisiana, Kansas, Wyoming, and Texas have created stewardship funds to cover limited longterm liability. These funds require CCS operators to pay a certain amount per metric ton of CO2 injected into a general fund that handles the long-term monitoring and liability of sites. Each of these funds covers slightly different aspects of the long-term liability. The likely impact of these funds on the CCS industry is not yet known, but their incomplete nature could lead to litigation and a reluctance of CCS industry members to engage in operations.

\section{Louisiana}

Louisiana created a CO2 Geologic Storage Trust Fund with HB 661 in 2009. With the creation of this fund, the state exempts operators and owners whose sites have been closed for ten years and received a completion of injection certificate showing that the site has complied with all permitting and safety requirements from "all liability associated with or related to that storage facility which arises after the issuance of the certificate of completion” (Louisiana HB $661 \S 1109$ (A), 2009). Additionally, the injector and owner are released from performance bonds when they receive their certificate of completion of injection operations. With this exemption of liability, the state assumes ownership of the site. However, the Bill also declares that "the state shall not assume or have any liability by the mere act of assuming ownership of a storage facility" (Louisiana HB 661 §1109(A)(2), 2009). Therefore, by assuming ownership of the site, the state is only agreeing to have the site cared for by the CO2 Geologic Storage Trust Fund, which does not provide comprehensive coverage and could be exhausted, and not assuming comprehensive liability. In this way, HB 661 creates a liability responsibility vacuum, making it neither the duty of the state nor the owner or operator.

This fund is collected from a monthly fee incurred per metric ton of CO2 injected. The fee amount has not been set since the trust fund has not yet been set up. The injector must pay the fee for a minimum of 120 months; no more than \$5 million can be collected from each injector (Louisiana HB $661 \S 1110$ (C), 2009). The fund only provides money for operational and longterm monitoring and repair of mechanical problems with injection wells or other types of leaks (HB $661 \S 1110$ (E), 2009). If damages deplete the fund, future projects may not be covered, but more importantly, the existing project has no other recourse for cleanup funds because the state does not indemnify the project or assume liability if this fund dries up. Furthermore, climate liability for escaped tons of CO2 would not be covered by this fund. The Bill sets civil liability caps for the owner at \$250,000 for non-economic losses, except for death and major injury. "Permanent physical or mental injury that prevents independent care and prevents life-sustaining activities" cannot exceed $\$ 500,000$. However, after ownership has been transferred to the state for the post-closure time frame, it is unclear where payments for this type of tort liability would come from since the state can only pay for mechanical repair and monitoring from the fund and assumes no responsibility for civil or climate liability. 


\section{$\underline{\text { Kansas }}$}

With HB 2419 passed in 2007, Kansas created the Carbon Dioxide Injection Well and Underground Storage Fund, to be used for expenses related to GS site permitting, regulatory oversight, enforcement, as well as long-term monitoring and remediation. The Kansas Corporation Commission (KCC) set fees for this fund at \$.05/metric ton injected (Carbon Dioxide Storage Facilities, 2010). The KCC is allowed to subject properties and facilities to this fund in order to prevent the release of $\mathrm{CO} 2$, which incurs a penalty of $\$ 10,000$ per violation per day under the Carbon Dioxide Reduction Act (Kansas HB 2419 §3, 2007).

Further details regarding the extent of liability transfer to the state and what the fund will cover are unclear as the remainder of HB 2419 has no mention of liability and instead covers accelerated depreciation for CCS equipment and exemptions of property taxes for landowners who have CCS operations on their property. The draft of HB 2419 in July of 2009 proposed that after the state approves post-closure status "any financial assurance instrument maintained by the facility operator shall be released ... .[and] Any future remediation or monitoring activities will be performed by the state using funds from the commission's CO2 remediation fund” (Postclosure Determination, 2010). By February 2010 when the rules for the Bill were adopted, this language was omitted. Therefore, it is unclear exactly what the fund covers since it is not specified in HB 2419, and it is not explicitly stated to cover tort, climate, or remediation and monitoring.

\section{Wyoming}

In 2010, Wyoming passed HB 17, which created the Geologic Sequestration Special Revenue Account, which is for the measurement, monitoring and verification of geologic sequestration sites following site closure certification (Wyoming HB 17 §1, 2010). The fee per metric ton injected has not yet been decided. Despite Wyoming's creation of this fund, HB 17 states that "The existence, management and expenditure of funds from this account shall not constitute a waiver by the state of Wyoming of its immunity from suit, nor does it constitute an assumption of any liability by the state for geologic sequestration sites” (HB 17 §1(d), 2010). This ambiguous statement seems to leave liability in question since the State of Wyoming takes over some monitoring of the site, but neither assumes nor releases operators from any liability. And, the state does leave open the possibility that it could be sued for damages resulting from CCS.

\section{$\underline{\text { Texas }}$}

Texas created a fund for long-term stewardship for on-shore geologic sequestration sites in 2009 with SB 1387 and designated the railroad commission as the entity in charge of adopting the rules and procedures for this fund (Texas SB 1387, 2009). The Anthropogenic Carbon Dioxide Storage Trust Fund is authorized to pay for expenses related to CCS site permitting, regulatory oversight, enforcement, as well as long-term monitoring and remediation of mechanical leaks. Interestingly, the fund also covers technology transfer of CCS and compliance and enforcement of well operations. Fees for this fund are to be determined by rule-making procedures. Rules may flesh out details regarding long-term site management and whether or not the fund could cover unintended migration of CO2 (Texas, 2010). A preliminary report on SB 1387 will address the "allocation of long-term liability for the post-operational phases of geologic storage projects" (Texas, SB $1387 \S 10$ (c)(5)(B)). At this point, however, the long-term civil and climate liabilities remain unaddressed. 
Long-term stewardship for off-shore CCS sites that are within 12 miles of the coast and still within the territory of Texas is covered by SB 1796 (2009). Under this Bill, the state, specifically the School Land Board, would be the owner of offshore CCS sites, and is authorized to operate the site and set fees for $\mathrm{CO} 2$ storage. The producer of the CO2 holds title to the injected $\mathrm{CO} 2$ until the state certifies that storage is permanent, at which point the state takes title. The Bill specifies that "the transfer of title to the state . . . does not relieve a producer of carbon dioxide of liability for any act or omission regarding the generation of stored carbon dioxide performed before the carbon dioxide was stored," such as when the CO2 traveled to the site in a pipeline (Texas SB 1796 §382.508, 2009). However, "the producer of the carbon dioxide is relieved of liability for any act or omission regarding the carbon dioxide in the carbon dioxide repository" (Texas SB $1796 \S 382.508,2009$ ). It is interesting to note that while the state of Texas does not assume ownership of the stored CO2 or provide comprehensive liability for on-shore CCS sites through SB 1387, it does assume this responsibility and liability for off-shore sites through SB 1796.

Table 1. Fees to State Geological Sequestration Funds

\begin{tabular}{|l|l|l|l|}
\hline State & Application fee & Annual fee & Per ton fee \\
\hline Louisiana $^{1}$ & & & $\begin{array}{l}\text { Not to exceed }(\$ 5 \\
\text { million/120 } \\
\text { months)/volume } \\
\text { injected }\end{array}$ \\
\hline Kansas $^{2}$ & $\$ 4,500+\$ 100 /$ well & $\$ 1,000 /$ well & $\begin{array}{l}\$ 0.05 / \text { metric ton } \\
\text { CO2 }\end{array}$ \\
\hline Texas $^{3 *}$ & $\$ 75,000$ & $\begin{array}{l}\$ 50,000 \text { for each } \\
\text { year post-injection } \\
\text { and pre-closure }\end{array}$ & $\begin{array}{l}\$ 0.10 / \text { metric ton } \\
\text { CO2 }\end{array}$ \\
\hline $\begin{array}{l}\text { North Dakota } \\
\text { admin fund }\end{array}$ & & & $\begin{array}{l}\$ 0.01 / \text { metric ton } \\
\text { CO2 }\end{array}$ \\
\hline $\begin{array}{l}\text { North Dakota } \\
\text { long-term fund }\end{array}$ & $\begin{array}{l}\$ 150+\text { actual } \\
\text { processing costs }\end{array}$ & & $\begin{array}{l}\$ 0.07 / \text { metric ton } \\
\text { CO2 }\end{array}$ \\
\hline
\end{tabular}

${ }^{1}$ H.B. 661 §1109 (La 2009).

${ }^{2}$ H.B. 2419 § 3 (Ks 2007).

${ }^{3}$ S.B. 1387, $81^{\text {st }}$ Gen. Sess. (Tx 2009).

${ }^{4}$ S.B. 2095, 61 $1^{\text {st }}$ Leg., Gen. Sess. (ND 2009)

* for sites in reservoirs which may be productive of oil or gas, but whose primary purpose is not EOR

\section{Indemnification}

In order to promote CCS, some states have offered to provide indemnification of liability. In the US, the states of Texas and Illinois both offered this luxury for the FutureGen project proponents as they competed for federal funding. Through legislation, the State of Texas offered to transfer the property rights of the $\mathrm{CO} 2$ from the operator to the state and then exempt the project from tort liability. Subsequently, the State of Illinois passed legislation that involved the transfer of title of CO2, the purchase of third party insurance for long-term storage if available, and indemnification for the FutureGen operator (Klass \& Wilson, 2008).

The government of Alberta has taken this concept even further by assuming long-term liability for all CCS sites (Brooysman, 2010). This blanket assumption of liability in Alberta may have seemed logical to Albertans since the Crown owns all subsurface minerals. 
This type of liability assumption in the US, however, is likely to only be offered for only a discreet number of demonstration projects in order to stimulate the industry. It is not likely to provide a means for long-term support of the industry.

\section{Three-Tiered Liability}

The EPA has considered a three-tiered CCS liability proposal, much like the Price-Anderson Nuclear Industries Indemnity Act of 1957 for nuclear generators. The Price-Anderson Act was created in the late 1950s as a method to incentivize private development of nuclear power while still providing adequate compensation to victims of accidents tied to the industry. The nuclear developers' concerns in the 1950s were similar to those of CCS developers today; the available insurance offerings did not seem adequate to cover catastrophic events, and therefore developers were wary of entering into contracts to begin activities with potentially high financial risks (Indemnification and limitation of liability, 2005).

The Price-Anderson Act involves a shared liability between the operator and general public, which may be more palatable than full federal or state assumption of liability. Nuclear generators pay for insurance that is capped at $\$ 375$ million total liability per facility. If an accident depletes the individual plant insurance (the first tier of insurance), then the pooled-industry fund that totals $\$ 12.2$ billion is tapped. This Fund is collected after the accident from each of the operating plants. Each plant must pay \$17.5 million per year up to a maximum of \$119 million per incident into this Fund if needed (Indemnification and Limitation of Liability, 2010; Inflation Adjustment to the Price-Anderson Act, 2008). Finally, if this Fund is depleted, then the federal government assumes liability and indemnifies the operator (US EPA, 2008).

This three-tiered liability places some responsibility on the individual operator and then shares responsibility with the industry as a whole. This scheme has the advantage that it creates a type of peer pressure on both the operator and the industry as a whole to be responsible (Rankin, 2009). This approach would have to be tailored for CCS since the appropriate minimum amount of insurance purchased may be contingent upon the amount of CO2 injected in the site. So, instead of requiring all facilities to purchase the mandated level of \$375 million in insurance as occurs in the nuclear industry, perhaps for CCS the amount of insurance purchased could be directly proportional to the amount of $\mathrm{CO} 2$ injected and/or an assessment of the reservoir's suitability. Likewise, instead of having industry participants pay retroactively for accidents that occur, perhaps a fee per metric ton should be collected so that the Fund could accumulate over time, even after CCS operators retire. A fund that accumulates in this way could help pay for ongoing maintenance and remediation. 
NOTICE: This is the author's version of a work accepted for publication by Elsevier. Changes resulting from the publishing process, including peer review, editing, corrections, structural formatting and other quality control mechanisms, may not be reflected in this document. Changes may have been made to this work since it was submitted for publication. The definitive version has been published in The Electricity Journal , Volume 24, Issue 3, 2011. DOI: 10.1016/j.tej.2011.03.001

Figure 2: Summary of Existing Liability Schemes in the US

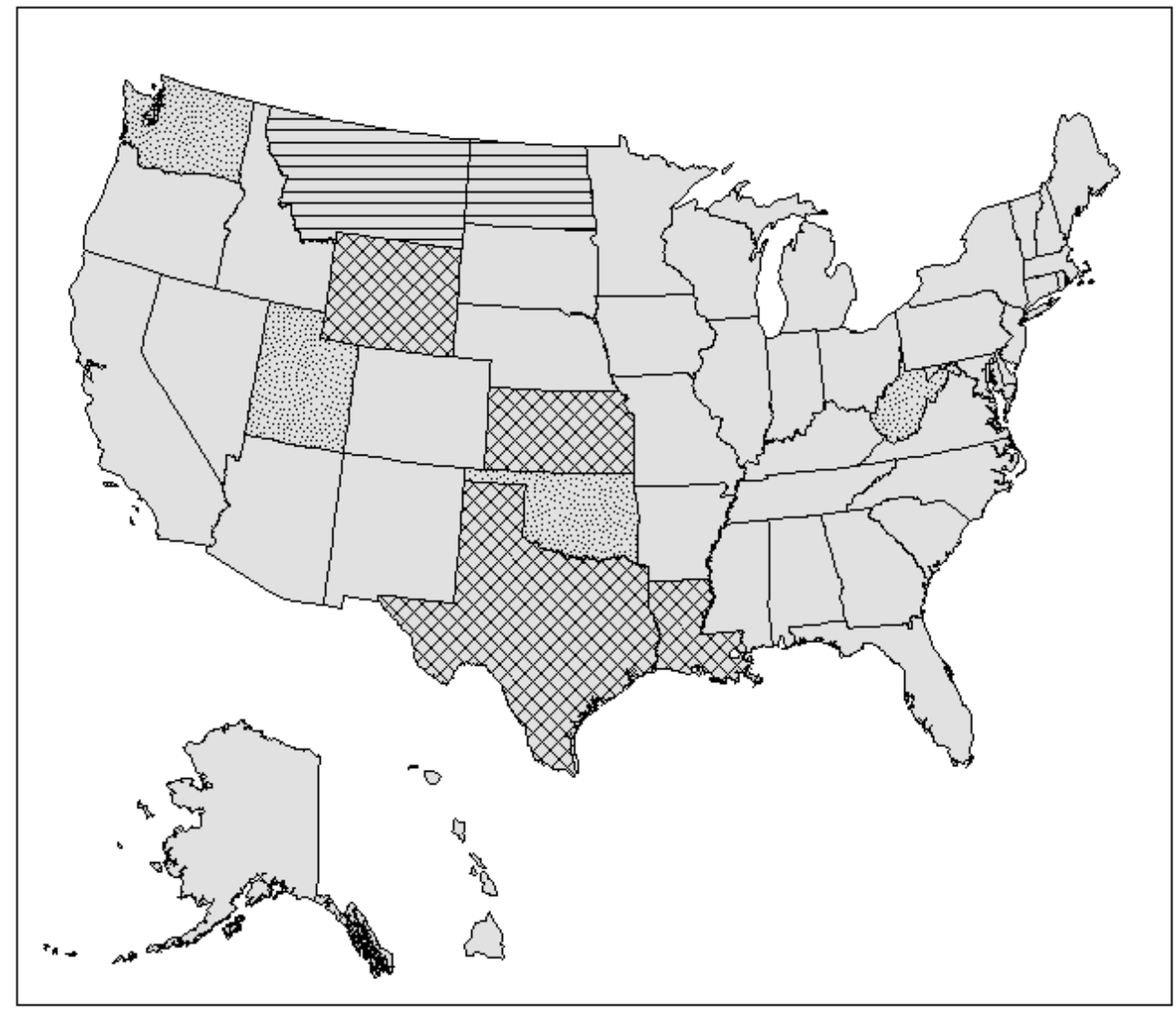

\section{Existing Liability Schemes}

UIC Class VI Well Rules in Place

Long-term stew ardship fund with state assum ing long-term limited liabilities Long-term stew ardship fund with state assum ing all long-term liabilities

Established permits or CCS rules but no liability assumption 
Figure 3: Summary of Short and Long-Term Liability Schemes (Adapted from Wilson et. al., 2007).

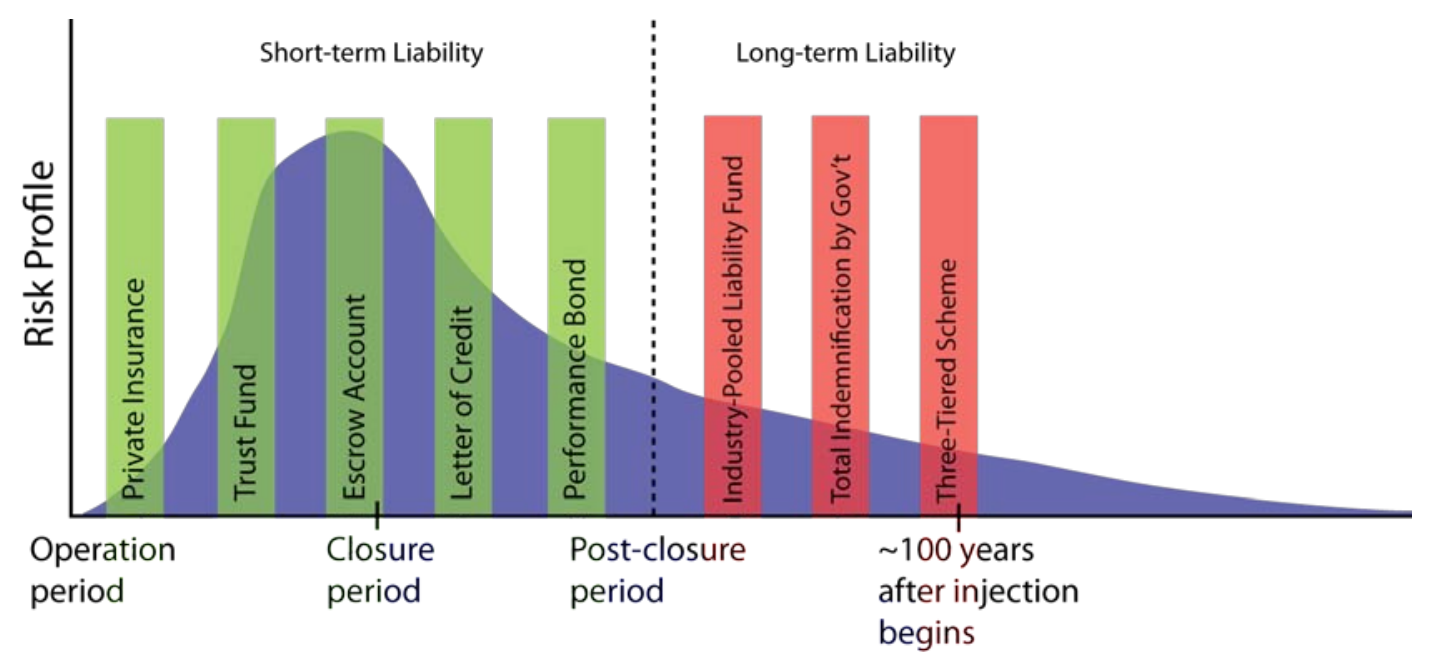

\section{Analysis and Recommendation of Best Scheme}

Very few of the liability schemes that have thus far been implemented, with the exception of the schemes in Alberta, North Dakota, and Montana, cover long-term liability in a comprehensive way. As a result, these incomplete liability schemes are likely to cause confusion, misunderstandings, and litigation as they are implemented.

The liability schemes implemented in Louisiana, Kansas, Wyoming, and Texas fail to provide coverage of civil and climate liabilities. While these states have made efforts to set up funds that cover the monitoring and remediation of CCS sites in the future, these funds do not cover civil or climate liabilities. And, these states have taken differing approaches to the amount of ownership of CO2 and liability they assume. Louisiana has stated in its law that neither the owner nor the state is responsible for the CO2 after closure (Louisiana HB 661 §1109(A)(2), 2009). Kansas’s law does not mention transfer of liability or ownership of the CO2 (Kansas HB 2419 §3, 2007). Wyoming claims that the state is neither liable for nor immune from suit for damages from the CO2 in the long-term (Wyoming HB $17 £ 1,2010$ ). Texas has assumed liability and ownership of the CO2 from offshore applications, but is silent on this issue for onshore CCS operations (Texas SB 1796, 2009; Texas SB 1387, 2009).

The liability schemes implemented in Alberta, North Dakota, and Montana involve the state or province taking title to the $\mathrm{CO} 2$ and assuming the long-term liability after a designated period of time. North Dakota and Montana have set up funds for long-term management; both of these funds are based on a charge per metric ton of CO2 injected (North Dakota SB 2095, 2009; Montana SB 498, 2009). These schemes are similar to an Interstate Oil and Gas Compact Commission (IOGCC) proposal calling for a 10-year closure period followed by monitoring and remediation with a fund that is generated from payments made by CCS operators (IOGCC, 2007). 
While these schemes may be successful at the state and provincial level, assumption of this much liability by the federal government or by other states may not be feasible or desirable.

Essentially, the type of fund created by North Dakota and Montana and proposed by the IOGCC has two tiers. The first tier consists of an industry-generated fund with revenues from injectors. If funding from this tier is depleted, then the second tier, which allows the state to indemnify the project and assume all liability, is utilized. Until the first tier has accumulated funds to cover a disaster, this type of liability scheme essentially involves the state assuming all liability for the project and indemnifying it. Similar to full indemnification provided by Alberta, Indiana and Texas for the FutureGen project, this system places a large burden on the public to help subsidize this industry. The pitfall of this industry-pooled fund not being available until adequate funds have been paid into it is definitely a "chicken-and-egg" problem. To overcome this problem, the fund could start with an initial minimum balance borrowed by the US Treasury (Jacobs \& Stump, 2010). Since an operator will not pay into the fund indefinitely, use of this industry fund to cover monitoring and remediation costs of old sites necessitates the existence of future CCS operators who will pay into this fund.

These two-tiered proposals mimic a CERCLA post-closure liability fund that was imposed until the mid-1980s. Under this now defunct scheme, hazardous waste disposal operators could apply to have liability and future monitoring and maintenance costs covered by an industry-generated fund, capped at \$200 million, after they had operated for 5 years and remained within the confines of their permits. This fund, however, was abandoned in the mid-80s because it was discovered that there was less incentive for hazardous waste disposal operators to pursue permanent management techniques when they knew that they would not be responsible for the site in the medium- and long-terms (Rankin, 2009). Likewise, two-tiered state liability schemes that transfer all liability away from the operator too soon after operations end or closure begins may not place enough responsibility on individual site managers and may also fail to adequately incentivize the long-term stewardship of the site. Due to the drawbacks of a two-tiered liability structure, consideration of a three-tiered approach is necessary.

The three-tiered approach to liability seems to provide the best solution for CCS as it balances comprehensive coverage with the need to allow the CCS industry to grow and share the responsibility of the site with both the owner/operator and the public, who will both benefit from CCS through carbon credits and fewer greenhouse gases in the atmosphere. However, it quickly becomes apparent that this scheme really is not much different from the two-tiered approach mentioned above. The first tier of liability borne by the owner/operator is limited by the insurance product that the owner/operator can buy. Currently, private insurance companies like Zurich Financial Services Group are only just beginning to be interested in insuring the operations and closure period of CCS (Zurich creates two new insurance policies, 2009). The infinite nature of the post-closure stage will prevent an individual insurance policy from being covered by these companies. Therefore, the three-tiered liability may not work as seamlessly as it did for the nuclear industry, which has a more limited 40-year time horizon, and this scheme may really resemble a two-tiered liability scheme that requires transfer of liability to the industrypooled fund after the closure phase.

Given these considerations, the best long-term liability scheme for CCS is probably a two-tiered scheme that transfers liability after a prescribed length of time, which is long enough to require 
NOTICE: This is the author's version of a work accepted for publication by Elsevier. Changes resulting from the publishing process, including peer review, editing, corrections, structural formatting and other quality control mechanisms, may not be reflected in this document. Changes may have been made to this work since it was submitted for publication. The definitive version has been published in The Electricity Journal , Volume 24, Issue 3, 2011. DOI: 10.1016/j.tej.2011.03.001

the operator to bear a significant portion of the responsibility but not too long so as to make coverage by a private company impossible. Therefore, the schemes set up by Montana and North Dakota will most likely provide CCS with the greatest chance of being successfully commercialized and provide an adequate level of protection against possible damages. However, these state-level schemes will most likely need to be superseded by the federal government in order to provide the depth of coverage necessary. 


\section{References}

Brooymans, H. (2010, November 1) Alberta to assume liability for long-term carbon storage. The Vancouver Sun. Retrieved from: http://www.vancouversun.com/technology/Alberta+assume+liability+long+term+carbon +storage/3761163/story.html

Carbon Dioxide Storage Facilities. Kansas Adm. Reg. 82-3-1100 to 1120. (2010).

Eddington, S. (4 March 2011). 'Fracking' disposal sites suspended, likely linked to Arkansas earthquakes. The Huffington Post. Retrieved from: http://www.huffingtonpost.com/2011/03/06/fracking-arkansasearthquakes_n_831633.html

Energy Information Administration. (2010a). Annual Energy Outlook with Projections to 2035. Retrieved from: http://www.eia.doe.gov/oiaf/aeo/demand.html.

Energy Information Administration. (2010b). International Energy Outlook 2010. Retrieved from: http://www.eia.doe.gov/oiaf/ieo/emissions.html

Environmental Protection Agency (2008). Approaches to Geologic Sequestration Site Stewardship After Site Closure. Office of Water. EPA 816-B-08-002. Retrieved from: http://www.epa.gov/ogwdw000/uic/pdfs/support_uic_co2_stewardshipforsiteclosure.pdf

Federal Requirements Under the Underground Injection Control (UIC) Program for Carbon Dioxide (CO2) Geologic Sequestration (GS) Wells, 75 Fed. Reg. 77230, (2010) (to be codified at 40 C.F.R. pt. 124, 144, 145, 146, and 147.

Freudenthal, D. (2008). Carbon Sequestration: A Lawyer's Cornucopia or Pandora's Box? Wyoming Lawyer Review, 31 (1).

Gresham, R. L., McCoy, S. T., Apt, J., \& Morgan, M. G. (January 01, 2010). Implications of compensating property owners for geologic sequestration of CO2. Environmental Science \& Technology, 44, 8, 2897-903.

Healy, J.H.; Rubey, W.W.; Griggs, D.T. \& Raleigh, C.B. (1968). The Denver Earthquakes. Science 161(3848), p. 1301-1310.

H.B. $661 \S 1109$ (La 2009). Conservation: Provides with respect to the geological sequestration of carbon dioxide, Cessation of storage operations; liability release. Retrieved from: http://www.legis.state.la.us/billdata/streamdocument.asp?did=659193

H.B. 2419 § 3 (Ks 2007). Carbon Dioxide Reduction Act. Retrieved from: http://www.kansas.gov/government/legislative/bills/2008/2419.pdf 
H.B. $17 \S 1,60^{\text {th }}$ Gen. Sess. (Wy 2010). Geologic sequestration special revenue account. Retrieved from: http://legisweb.state.wy.us/2010/Enroll/HB0017.pdf

Indemnification and Limitation of Liability, 42 U.S.C. § 2210 (2010). Retrieved from: http://www.law.cornell.edu/uscode/42/usc_sec_42_00002210----000-.html

Inflation Adjustment to the Price-Anderson Act Financial Protection Regulations, 73 Fed. Reg. 56451, (2008) (to be codified at 10 C.F.R. pt. 140).

Interagency Task Force on Carbon Capture and Storage. (2010). Report of the Interagency Task Force on Carbon Capture and Storage. Retrieved from: http://www.epa.gov/climatechange/policy/ccs_task_force.html

Intergovernmental Panel on Climate Change (IPCC). (2005). Special Report on Carbon Dioxide Capture and Storage. Edited by Bert Metz, Ogunlade Davidson, Heleen de Coninck, Manuela Loos \& Leo Meyer. Cambridge University Press, UK. pp. 431.

Interstate Oil \& Gas Compact Commission. (2007). CO2 Storage: A legal and regulatory guide for states. Retrieved from: http://iogcc.myshopify.com/collections/frontpage/products/co2-storage-a-legal-andregulatory-guide-for-states-2008

Jacobs, W. \& Stump, D. (2010). Proposed Liability Framework for Geological Sequestration of Carbon Dioxide. Emmett Environmental Law and Policy Clinic and Harvard Law School. Retrieved from: http://www.law.harvard.edu/programs/about/elp/ccswhitepaper.pdf

Klass, A.B. \& Wilson, E.J. (2008). Climate change and carbon sequestration: Assessing a liability regime for long-term storage of carbon dioxide. Emory Law Journal 58, p. 108180.

Klass, A.B. \& Wilson, E.J. (2009). Carbon capture and sequestration: Identifying and managing risks. Issues in Legal Scholarship 8(3). (Balancing the risks: Managing technology and dangerous climate change).

Knott, T. (2008). Sealed under the Sahara. Frontiers, 23. Published by BP Global online at: http://www.bp.com/sectiongenericarticle.do?categoryId=9027098\&contentId=7049642

National Energy Technology Laboratory. (2009). Storage of captured carbon dioxide beneath federal lands. DOE/NETL-2009/1358. Retrieved from: http://www.netl.doe.gov/energyanalyses/pubs/Fed\%20Land_403.01.02_050809.pdf

North Dakota Industrial Commission, Department of Mineral Resources, Oil and Gas Division Rules and Regulations. (2010). 43-05-01-17. Storage Facility Fees. Retrieved at: https://www.dmr.nd.gov/oilgas/rules/rulebook.pdf 
Official Journal of the European Union. (13 October 2003). Directive 2003/87/EC of the European Parliament and of the Council of 13 October 2003 on establishing a scheme for greenhouse gas emission allowance trading within the Community and amending Council Directive 96/61/EC. Retrieved from: http://eurlex.europa.eu/LexUriServ/LexUriServ.do?uri=OJ:L:2003:275:0032:0032:EN:PDF.

Official Journal of the European Union. (21 April 2004). Directive 2004/35/CE of the European Parliament and of the Council of 21 April 2004 on environmental liability with regard to the prevention and remedying of environmental damage. Retrieved from: http://eurlex.europa.eu/LexUriServ/LexUriServ.do?uri=CELEX:32004L0035:EN:NOT

Official Journal of the European Union. (6 May 2009). Directive 2009/31/EC of the European Parliament and of the Council of 23 April 2009 on the geological storage of carbon dioxide and amending Council Directive 85/337/EEC, European Parliament and Council Directives 2000/60/EC, 2001/80/EC, 2004/35/EC, 2006/12/EC, 2008/1/EC and Regulation (EC) No 1013/ 2006. Retrieved from: http://eurlex.europa.eu/LexUriServ/LexUriServ.do?uri=OJ:L:2009:140:0114:0135:EN:PDF

Pacala, S. \& Socolow, R. (2004). Stabilization Wedges: Solving the Climate Problem for the Next 50 Years with Current Technologies. Science 305: 968-972.

Petro-Find Geochem, Ltd. (2011). Geochemical soil gas survey. A site investigation of SW30-513-W2M. Weyburn Field, Saskatchewan. Retrieved from: http://www.ecojustice.ca/media-centre/media-release-files/petro-find-geochem-ltd.report/at_download/file

Postclosure determination. Kansas Adm. Reg. 82-3-117 (d). (2010).

Rankin, A. G. (2009). Geologic Sequestration of CO2: How EPA's proposal falls short. Natural Resources Journal, 49, p. 883-942.

S.B. $1387,81^{\text {st }}$ Gen. Sess. (Tx 2009). relating to the implementation involving the capture, injection, sequestration, or geologic storage of carbon dioxide. Retrieved from: http://www.legis.state.tx.us/billlookup/Text.aspx?LegSess=81R\&Bill=SB1387

S.B. 1796 §382.508 (Tx 2009). Texas Health and Safety Code- Offshore geologic storage of carbon dioxide. Retrieved from: http://www.legis.state.tx.us/tlodocs/81R/billtext/html/HB01796F.HTM

S.B. 2095, 61 $1^{\text {st }}$ Leg., Gen. Sess. (ND 2009) relating to the geologic storage of carbon dioxide. Retrieved from: http://www.legis.nd.gov/assembly/61-2009/bill-text/JQTA0300.pdf

S.B. 498, $61^{\text {st }}$ Leg., Gen. Sess. (Mt 2009) relating to permitting for carbon dioxide injection wells. Retrieved 11/18/10 from: http://data.opi.mt.gov/bills/2009/BillPdf/SB0498.pdf 
The Texas General Land Office, The Railroad Commission of Texas, The Texas Commission on Environmental Quality, The Bureau of Economic Geology. (2010). Injection and geologic storage regulation of anthropogenic carbon dioxide: A preliminary joint report to the legislature required under Sections 9 and 10 of SB 1387, 81st Leg, 2009. Retrieved from: http://www.rrc.state.tx.us/forms/reports/notices/SB1387-FinalReport.pdf

United States Department of Energy. (2011). Enhanced Oil Recovery/ CO2 Injection. Retrieved from: http://www.fossil.energy.gov/programs/oilgas/eor/index.html

Wilson, E.J.; de Figueiredo, M.A.; Trabucchi, C.; Larsen, K. (2007). Liability and financial responsibility frameworks for carbon capture and sequestration. World Resources Institute Issue Brief, Carbon Capture \& Sequestration, 3. Retrieved from: http://pdf.wri.org/liability-and-financial-responsibility.pdf.

Zurich creates two new insurance policies to support greenhouse gas mitigation technologies, addressing the unique needs of carbon capture and sequestration. (2009, January 19). Business Wire. Retrieved from: http://www.businesswire.com/news/home/20090119005535/en/Zurich-creates-insurancepolicies-support-green-house 